\title{
INDIVIDUAL AND COMBINED GROWTH-PROMOTING MICROORGANISMS AFFECT BIOMASS PRODUCTION, GAS EXCHANGE AND NUTRIENT CONTENT IN SOYBEAN PLANTS ${ }^{1}$
}

\author{
MARIANA AGUIAR SILVA ${ }^{2 *}$, ADRIANO STEPHAN NASCENTE ${ }^{3}$, MARTA CRISTINA CORSI DE FILIPPI $^{3}$, ANNA \\ CRISTINA LANNA ${ }^{3}$, GISELE BARATA DA SILVA ${ }^{4}$, JOSÉ FRANCISCO ARRUDA E SILVA ${ }^{3}$
}

\begin{abstract}
The use of beneficial microorganisms in crop systems can contribute to sustainable agriculture by promoting improvements in crop development and grain yield without damaging the environment. However, there is much uncertainty surrounding the effects of using a combination of microorganisms to promote plant development. The objective of this work was to determine the effects of microorganism species individually and in combination on the biomass production, gas exchange and nutrient contents in the shoots and roots of soybean plants. The experimental design was completely randomized, with 30 treatments and three replicates. The treatments consisted of the application of the rhizobacteria BRM 32109, BRM 32110 and 1301 (Bacillus sp.); BRM 32111 and BRM 32112 (Pseudomonas sp.); BRM 32113 (Burkholderia sp.); BRM 32114 (Serratia sp.); Ab-V5 (Azospirillum brasilense) and 1381 (Azospirillum sp.); the fungus Trichoderma asperellum (a mixture of the isolates UFRA. T06, UFRA. T09, UFRA. T12 and UFRA. T52); 19 combinations of these microorganisms, and a control (no microorganisms). At sowing, the soil was treated with Bradyrhizobium, and then the soybean seeds were inoculated. The microorganism suspension was applied in each treatment at 7 days after planting (DAP) in the soil and at 21 DAP on the seedlings. The Trichoderma pool, Ab-V5, 1301 + 32110, $1301+32114,1301+\mathrm{Ab}-\mathrm{V} 5$ and $32110+\mathrm{Ab}-\mathrm{V} 5$ treatments resulted in significantly higher total biomass accumulation in the soybean plants, with values that were, on average, $25 \%$ higher than that in the control treatment. Our results suggest that the use of beneficial microorganisms in cropping systems is a promising technique.
\end{abstract}

Keywords: Glycine max. Bioagent. Biomass. Growth promotion.

\section{MICRORGANISMOS PROMOTORES DE CRESCIMENTO ISOLADOS E COMBINADOS AFETANDO A PRODUÇÃO DE BIOMASSA, TROCAS GASOSAS E O CONTEÚDO DE NUTRIENTES EM PLANTAS DE SOJA}

\begin{abstract}
RESUMO - O uso de microrganismos benéficos nos sistemas de cultivo pode contribuir para a agricultura sustentável, promovendo melhorias no desenvolvimento das culturas e na produção de grãos sem danificar o meio ambiente. No entanto, há muita incerteza quanto aos efeitos do uso de uma combinação de microrganismos para promover o desenvolvimento da planta. O objetivo deste trabalho foi determinar os efeitos das espécies de microrganismos individualmente e em combinação na produção de biomassa, trocas gasosas e conteúdo de nutrientes na parte aérea e raízes das plantas de soja. O delineamento experimental foi inteiramente casualizado, com 30 tratamentos e três repetições. Os tratamentos consistiram na aplicação das rizobactérias BRM 32109, BRM 32110 e 1301 (Bacillus sp.); BRM 32111 e BRM 32112 (Pseudomonas sp.); BRM 32113 (Burkholderia sp.); BRM 32114 (Serratia sp.); Ab-V5 (Azospirillum brasilense) e 1381 (Azospirillum sp.); o fungo Trichoderma asperellum (uma mistura dos isolados UFRA. T06, UFRA. T09, UFRA. T12 e UFRA. T52); 19 combinações desses microrganismos e um controle (sem microrganismos). Na semeadura, o solo foi tratado com Bradyrhizobium e as sementes de soja foram inoculadas. A suspensão de microrganismos foi aplicada em cada tratamento aos 7 dias após o plantio (DAP) no solo e aos 21 DAP nas mudas. Os tratamentos pool de Trichoderma, Ab-V5, 1301 + 32110, $1301+32114,1301+$ Ab-V5 e $32110+$ Ab-V5 resultaram em acúmulo de biomassa total significativamente maior nas plantas de soja, com valores, em média, 25\% superior ao tratamento controle. Nossos resultados sugerem que o uso de microrganismos benéficos em sistemas de cultivo é uma técnica promissora.
\end{abstract}

Palavras-chave: Glycine max. Bioagente. Biomassa. Promoção de crescimento.

\footnotetext{
${ }^{*}$ Corresponding author

${ }^{1}$ Received for publication in $06 / 25 / 2019$; accepted in $04 / 08 / 2020$.

Paper extracted from the masters dissertation of the first author.

${ }^{2}$ School of Agronomy, Universidade Federal de Goiás, Goiânia, GO, Brazil; marianaaguiar23@hotmail.com - ORCID: 0000-0003-02975576.

${ }^{3}$ Embrapa Arroz e Feijão, Santo Antônio de Goiás, GO, Brazil; adriano.nascente@embrapa.br - ORCID: 0000-0002-6014-3797, cristina.filippi@embrapa.br - ORCID: 0000-0003-1676-8164, anna.lanna@embrapa.br - ORCID: 0000-0001-8018-9349, j.chikosilva@hotmail.com - ORCID: 0000-0002-0604-8174.

${ }^{4}$ Plant Protection Laboratory, Institute of Agrarian Sciences, Universidade Federal Rural da Amazônia, Belém, PA, Brazil; giselebaratasilva@gmail.com - ORCID: 0000-0002-6064-7864.
} 


\section{INTRODUCTION}

Soybean (Glycine max) is the main oil crop in the world, with a planted area of 124.580 million hectares and production of 336.699 million tons, of which Brazil contributes 115 million tons; the United States, the largest soybean producer, contributes 123.63 million tons (USDA, 2019). Currently, soybean is considered one of the best Brazilian agribusiness products, as it generates approximately 70 billion dollars a year (APROSOJA, 2018). This also makes soybean a high-priority research topic. Under current conditions, the research emphasis is on reducing the use of agrochemicals and fertilizers as well as on reducing production costs without losses in grain yield in order to make soybean cultivation sustainable and provide social, environmental and economic gains (NUNES, 2017).

One method for increasing the efficiency of chemical fertilizers and decreasing the amount of fertilizers applied in agricultural production environments is the use of microorganisms that promote plant growth (SPOLAOR et al., 2016). Among these microorganisms, plant growthpromoting rhizobacteria (PGPR) are notable. PGPR are able to improve plant development through different mechanisms, such as nutrient supplementation through biological nitrogen fixation, $\mathrm{P}$ and $\mathrm{Fe}$ solubilization, and siderophore production; inhibition of the development and action of pests and pathogens; and production of phytohormones, such as indole acetic acid (IAA), as well as antibiotic and antifungal compounds that induce rooting and plant growth and increase the tolerance of plants to biotic and abiotic stress (CARDOSO; ANDREOTE, 2016).

In addition to rhizobacteria, fungi of the genus Trichoderma are some of the main microorganisms that are important in increasing plant growth, as they have mechanisms of action that are very similar to those of PGPR. Trichoderma can positively influence seed germination, crop development and grain yield due to their production of growth-promoting substances and can improve plant nutrition, mainly by solubilizing phosphorus and synthesizing of indole-acetic acid (CHAGAS et al., 2016).

In this context, technological alternatives are being researched to improve soybean development and reduce the use of pesticides. Among these methods, we highlight the coinoculation of the soybean crop. This method consists of combining different microorganisms to create a synergistic effect on soybean in which the crop grain yield is higher than that under inoculation with only one microorganism (MAURÍCIO FILHO; SILVA; SOUZA, 2018). Research in this direction can contribute to increased soybean productivity, reduced production costs, and reduced environmental contamination caused by fertilizer misuse or high pesticide use, thereby promoting the sustainability of the agricultural system (MAURÍCIO FILHO; SILVA; SOUZA, 2018). However, in the literature, inconsistent results have been found from this technique. To circumvent this problem, it is necessary to improve and test the coinoculation technique with the goals of synergetic microorganism activity, improved dosing and application methods for these microorganisms and, consequently, improvements in their agronomic efficiency in the culture (BÁRBARO-TORNELI et al., 2018).

Studies by Embrapa Rice and Bean and the Federal Rural University of Amazonia allowed the identification of beneficial rhizobacteria collected from upland rice fields (FILIPPI et al., 2011) and four isolates of the fungus Trichoderma asperellum (UFRA. T06, UFRA. T09, UFRA. T12, UFRA. T52) (FRANÇA et al., 2015), respectively. After selection and characterization, greenhouse studies confirmed the potential use of these microorganisms, since significant increases were observed in the gas exchange parameters and biomass production of shoots of upland and irrigated rice plants (NASCENTE et al., 2017). However, these microorganisms were not evaluated in other crops, such as soybean. As soybean is one of the most important crops in Brazil, if these microorganisms promote increases in soybean development, it will have a significant impact on Brazilian agriculture. Therefore, the objective of this study was to determine the effect of these microorganisms, individually or in combination, on the biomass production, gas exchange parameters and nutrient contents of shoot and root systems in soybean plants.

\section{MATERIAL AND METHODS}

The study was conducted in a greenhouse at Embrapa Rice and Bean experimental farm, in Santo Antônio de Goiás, GO, Brazil. Arable-layer soil (0$0.20 \mathrm{~m}$ ), a dark red Latosol (Ácrico) (SANTOS et al., 2018), from an area that had been Urochloa brizantha pasture for more than 20 years was used. The chemical characteristics of the soil were determined according to the methods described by Donagema et al. (2011) (Table 1). 
M. A. SILVA et al.

Table 1. Chemical attributes of the soil used to grow soybean (Glycine max (L.) Merrill) plants in the experiment conducted in 2018 at Embrapa Rice and Beans.

\begin{tabular}{|c|c|c|c|c|c|c|c|c|c|c|c|c|c|c|}
\hline $\mathrm{pH}\left(\mathrm{H}_{2} \mathrm{O}\right)$ & $\mathrm{Ca}^{2+}$ & $\mathrm{Mg}^{2+}$ & $\mathrm{Al}^{3+}$ & $\mathrm{H}^{+}+\mathrm{Al}^{3+}$ & $\mathrm{P}$ & K & $\mathrm{Cu}^{2+}$ & $\mathrm{Zn}^{2+}$ & $\mathrm{Fe}^{3+}$ & $\mathrm{Mn}^{2+}$ & SOM & Clay & Silt & Sand \\
\hline & \multicolumn{10}{|c|}{--------------mmol $\mathrm{dm}_{\mathrm{c}}^{-3}$--------------- } & \multicolumn{4}{|c|}{----------------.g kg ${ }^{-1}-$} \\
\hline 5.0 & 7.3 & 2.1 & 1 & 26 & 0.6 & 56 & 2.2 & 1.1 & 37.5 & 16.1 & 19.91 & 444 & 127 & 429 \\
\hline
\end{tabular}

*SOM - Soil organic matter.

Three weeks before soybean sowing, $7 \mathrm{~kg}$ pots were filled with soil and fertilized with 10 grams of $\mathrm{N}-\mathrm{P}_{2} \mathrm{O}_{5}-\mathrm{K}_{2} \mathrm{O}$ (5-30-15). To provide a nitrogen supply, a liquid inoculant (Bradyrhizobium japonicum) was applied in the seeding groove of all pots, including the control treatment. Five milliliters of the commercial product "Grap Nod" was diluted in $900 \mathrm{ml}$ of water, and $10 \mathrm{ml}$ of the solution was applied per pot.

The experimental design was completely randomized, with 30 treatments and three replicates. The treatments consisted of the microbiolization of the soybean seeds with microorganisms, alone or in combination. The microorganisms included nine isolates of rhizobacteria and a pool of Trichoderma asperellum. At seven and 21 days after planting, suspensions of the microorganisms were sprayed on the soil and plants, respectively. The treatments were distributed as follows: (1) BRM 32109; (2) BRM 32110; (3) BRM 32111; (4) BRM 32112; (5) BRM 32113; (6) BRM 32114; (7) 1301; (8) 1381; (9) Trichoderma asperellum pool (T. pool); (10) Ab-V5;
(11) $32110+32114 ;$ (12) $1301+32110$; (13) $1381+$ 32110 ; (14) $1301+32114$; (15) $1381+32114$; (16) $1301+1381$; (17) $32110+\mathrm{Ab}-\mathrm{V} 5$; (18) $32114+\mathrm{Ab}$ -V5; (19) $1301+$ Ab-V5; (20) $1381+$ Ab-V5; (21) Ab-V5 + T. pool; (22) $32110+T$. pool; (23) $32114+$ $T$. pool; (24) $1301+T$. pool; (25) $1381+T$. pool; (26) $32110+32114+\mathrm{Ab}-\mathrm{V} 5$; (27) $32110+\mathrm{Ab}-\mathrm{V} 5+$ $T$. pool; (28) $32110+32114+\mathrm{Ab}-\mathrm{V} 5+T$. pool; (29) $32110+32114+\mathrm{Ab}-\mathrm{V} 5+T$. pool $+1301+1381$ and (30) control (no microorganisms).

The main characteristics of the rhizobacterial isolates (BRM 32109, BRM 32110 and 1301 (Bacillus sp.), BRM 32111 and BRM 32112 (Pseudomonas sp.), BRM 32113 (Burkholderia sp.), BRM 32114 (Serratia sp.), Ab-V5 (Azospirillum brasilense) and 1381 (Azospirillum sp.) are described in (Table 2). The rhizobacteria were identified in and collected from upland rice crop fields, and were stored and preserved in the Multifunctional Microorganisms Collection of Embrapa Rice and Beans.

Table 2. Collection code, geographical origin, biochemical characteristics and taxonomic classification of the eight rhizobacterial isolates used to treat the soybean seeds.

\begin{tabular}{|c|c|c|c|c|c|c|c|c|}
\hline \multirow{2}{*}{ Code $^{A}$} & \multirow{2}{*}{ Origin $^{B}$} & \multirow{2}{*}{ Color $^{\mathrm{C}}$} & \multicolumn{5}{|c|}{ Biochemical $^{\mathrm{D}}$} & \multirow{2}{*}{ Taxonomic $^{\mathrm{E}}$} \\
\hline & & & $\mathrm{IAA}^{\mathrm{F}}$ & Celul. $^{G}$ & Phos ${ }^{\text {Hor }}$ & Sider. $^{\top}$ & Biofilm & \\
\hline BRM 32109 & GO/Brazil & White & & + & + & + & + & Bacillus sp. \\
\hline BRM 32110 & PA/Brazil & White & & + & + & & + & Bacillus sp. \\
\hline BRM 32111 & PA/Brazil & Yellow & & + & + & + & + & Pseudomonas sp. \\
\hline BRM 32112 & GO/Brazil & Yellow & & + & + & + & + & Pseudomonas sp. \\
\hline BRM 32113 & PA/Brazil & Pink & + & + & & + & + & Burkholderia sp. \\
\hline BRM 32114 & PA/Brazil & Pink & + & + & + & + & + & Serratia sp. \\
\hline Ab-V5 & PR/Brazil & Yellow & + & + & + & + & + & Azospirillum sp. \\
\hline 1381 & & White & + & + & + & + & + & Azospirillum sp. \\
\hline 1301 & & White & + & + & + & + & + & Bacillus sp. \\
\hline
\end{tabular}

Numerical code of the rhizobacterial isolates in the Multifunctional Microorganisms collection of Embrapa Rice and Beans; Geographical origin of each isolate;

${ }^{\mathrm{C}}$ Colony color, ${ }^{\mathrm{D}}$ Biochemical characterization and ${ }^{\mathrm{E}}$ Taxonomic classification of each isolate, as described by Nascente et al. (2017);

${ }^{\mathrm{F}}$ Indole acetic acid producer; ${ }^{\mathrm{G}}$ Cellulase producer; ${ }^{\mathrm{H}}$ Phosphatase producer; ${ }^{\mathrm{I}}$ Siderophore producer; ${ }^{\mathrm{J}}$ Biofilm producer. 
The Trichoderma asperellum pool (a mixture of isolates UFRA-06, UFRA-09, UFRA-12 and UFRA-52) was collected from rhizosphere soils of reforestation areas and native forests in the Amazon, identified by Silva et al. (2012) and stored and preserved in the Collection of Fungi Culture of the Laboratory of Plant Protection of the Federal Rural University of Amazonia.

Bacterial suspensions for seed microbiolization and spray applications were prepared with water from cultures grown for 24 hours in solid medium 523 (KADO; HESKETT, $1970)$ at $28{ }^{\circ} \mathrm{C}$. The concentration was fixed at $10^{8}$ CFUs (colony forming units) per $\mathrm{ml}$, determined in a spectrophotometer at A540 $=0.5$. Microbiolization was carried out by soaking the soybean seeds in each suspension of microorganisms; the control seeds were immersed in water for 4 hours under constant agitation at $25{ }^{\circ} \mathrm{C}$ (FILIPPI et al., 2011). For $T$. asperellum, each isolate was grown in Petri dishes containing PDA (potato and dextrose agar) for five days and formulated as described by Silva et al. (2012). The seed treatment was carried out at concentrations of $10 \mathrm{~g}$ of $T$. asperellum powder for 1 $\mathrm{kg}$ of seeds (SILVA et al., 2012). Each isolate of Trichoderma asperellum was brought to $10^{8}$ conidia $\mathrm{ml}^{-1}$, and then the isolates were mixed in equal volumes.

Soybean seed microbiolization was performed based on the methodology used for rice seed microbiolization proposed by Filippi et al. (2011), with a modification. Before proceeding with soybean microbiolization, we performed a test to determine the optimal period of time for seed and bacterial suspension contact. Soybean seeds were immersed in a suspension containing water and the isolate BRM 32110 (Bacillus spp.) and in only water (control treatment) for different periods of time ( 2 hours, 4 hours, 6 hours and 16 hours) for a total of 5 treatments and 4 repetitions. The seeds were removed from the suspension, dried at room temperature and sown in $500 \mathrm{ml}$ cups. The best time period for exposure to the suspension was determined by identifying the tallest seedlings at 15 days after sowing. The best result occurred after microbiolization for 4 hours. Therefore, this methodology was used in this experiment.

Ten soybean seeds were sown per pot (cultivar BRS 6970IPRO). Seven days after germination, the plants were thinned to four plants per pot. The cultural practices were carried out under the technical recommendations for the crop in order to keep the area free of weeds, diseases and pest insects.

After sowing, two applications of the microorganism suspension were performed: 1) seven days after sowing (DAS), the soil was irrigated with $100 \mathrm{ml}$ of the bacterial isolates $\left(10^{8} \mathrm{CFU} \mathrm{ml}{ }^{-1}\right)$, with a suspension containing the T. asperellum pool $\left(10^{8}\right.$ conidia $\mathrm{ml}^{-1}$ ) or with water (control); 2) at $21 \mathrm{DAS}$, the plants were sprayed with $30 \mathrm{ml}$ of bacterial isolates $\left(10^{8} \mathrm{CFU} \mathrm{ml}^{-1}\right)$, with a suspension containing the $T$. asperellum pool $\left(10^{8}\right.$ conidia $\left.\mathrm{ml}^{-1}\right)$ or with water (control). Manual spraying was performed with a constant pressure supplied by a $\mathrm{CO}_{2}$ pressure source and a conical nozzle (TX-VS2).

\section{Gas exchanges}

Measurements were performed using an infrared gas analyzer (LCpro +, ADC BioScientific, Hoddesdon, England). One soybean plant per pot was used to perform the gas exchange measurements. The central leaflets of the upper third of the plants (completely expanded and exposed to sunlight) were used to determine the photosynthetic rate, $\mathrm{A}\left(\mu \mathrm{mol} \mathrm{CO}_{2} \mathrm{~m}^{-2} \mathrm{~s}^{-1}\right)$, transpiration rate, $\mathrm{E}$ (mmol $\mathrm{H}_{2} \mathrm{O} \mathrm{m}^{-2} \mathrm{~s}^{-1}$ ), stomatal conductance, gs (mol $\mathrm{H}_{2} \mathrm{O} \mathrm{m}^{-2} \mathrm{~s}^{-1}$ ) and leaf temperature, Tleaf (C). The measurements were taken from 08:00 am to 10:00 am in the full flowering stage of the soybean plants.

The equipment was regulated to use concentrations of $370-400 \mathrm{~mol} \mathrm{~mol}{ }^{-1} \mathrm{CO}_{2}$ in the reference air used in the IRGA photosynthesis chamber. The photosynthetically active photon flux density (PPFD) used was $1200 \mu \mathrm{mol}$ [quanta] $\mathrm{m}^{-2} \mathrm{~s}^{-1}$. The minimum equilibrium time established for the reading was 2 minutes.

\section{Shoot, root and total (shoot + root) dry biomass}

When the soybean plants reached the full flowering stage (40 days), the shoots were cut and wrapped in correctly identified envelopes. For the roots, the soil was washed and sifted to separate out the roots, and the roots were packed in correctly identified envelopes. Both shoots and roots were dried in a forced ventilation oven at $65{ }^{\circ} \mathrm{C}$ until reaching a constant mass. Then, the material in each envelope was weighed to determine the dry shoot, root and total (shoot + root) biomass.

\section{Shoot and root macronutrients}

The soybean shoots and roots from each treatment, after drying and weighing, were ground in a Wiley mill for analysis and determination of their nutrient contents $(\mathrm{N}, \mathrm{P}, \mathrm{K})$. Nitrogen was extracted with $\mathrm{H}_{2} \mathrm{SO}_{4}$. From the extracted solution, the $\mathrm{N}$ concentration was determined using the Kjeldahl distillation method (MALAVOLTA; VITTI; OLIVEIRA, 1997). Phosphorus and exchangeable K were extracted with a Mehlich extracting solution $\left(0.05 \mathrm{M} \mathrm{HCl}\right.$ in $\left.0.0125 \mathrm{M} \mathrm{H}_{2} \mathrm{SO}_{4}\right)$. The extracts were colorimetrically analyzed for $\mathrm{P}$, and flame photometry was used to analyze K (DONAGEMA et al, 2011).

\section{Statistical analyses}


The data were subjected to analysis of variance, and means were compared by the LSD test $(\alpha \leq 0.05)$. Dunnett's test $(\alpha \leq 0.05)$ was used to compare the control (no microorganisms) with the treatments with microorganisms. The statistical package used was SAS (SAS, 1999). A multivariate principal component analysis (PCA) was performed to describe the correlations between response variables (i.e., gas exchange; shoot, root and total biomass production; and accumulation of nutrients in the shoot and roots) and microorganisms alone and in combination. The main components (PCs) were loaded with response variables when the correlation test produced $\mathrm{r} \geq 0.50$. The first three PCs responsible for $>65 \%$ of the data variation were retained. Biplots (two-dimensional graph) of these three PCs correlating the isolated and combined microorganisms and the response variables were built with the "FactoExtra" package (KASSAMBARA, 2015) in the R platform.

\section{RESULTS AND DISCUSSION}

The analysis of variance showed that there were significant differences in gas exchange and dry shoot, root and total biomass as well as in shoot and root macronutrient content among treatments with different growth-promoting microorganisms alone or in combination (Figures 1, 2, 3, 4 and 5). Compared to that in the control, a significant increase in the photosynthetic rate (A) was observed in plants treated with BRM 32109, followed by the increases from BRM 32111 and 1301 (Figure 1A). According to Nascente et al. (2017), growth-promoting rhizobacteria improve the physiological characteristics of plants, especially the photosynthetic rate. This is due to the ability of these bacteria to produce plant hormones and increase plant absorption of macronutrients (CANELLAS et al., 2015) such as N, P and K, which influence plant gas exchange rates.

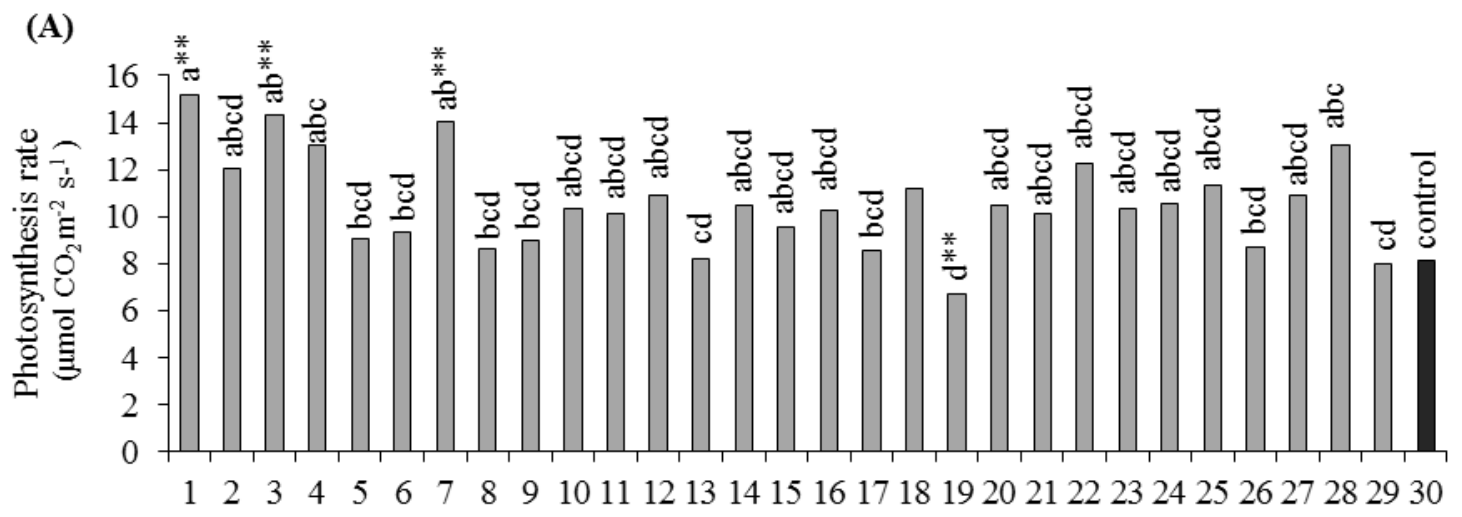

(B)

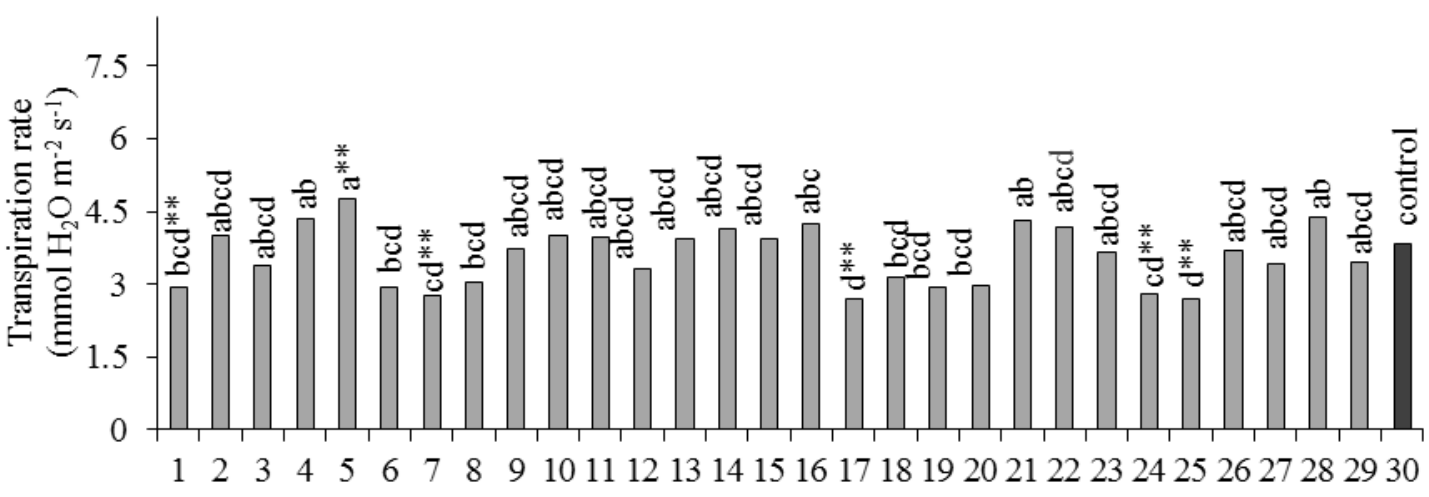

Figure 1. (A) Photosynthesis, A and (B) transpiration rate, E of soybean plants treated with beneficial microorganisms alone or in a mixture. *Means followed by the same letter in columns do not differ from each other by the LSD test. Comparisons between the treatments and the control that were significant by the Dunnett test at a significance level of 0.05 are indicated by **. Treatments: (1) BRM 32109; (2) BRM 32110; (3) BRM 32111; (4) BRM 32112; (5) BRM 32113; (6) BRM 32114; (7) 1301; (8) 1381; (9) T. asperellum pool (T. pool); (10) Ab-V5; (11) $32110+32114$; (12) $1301+32110$; (13) $1381+32110$; (14) $1301+32114$; (15) $1381+32114$; (16) $1301+1381$; (17) $32110+\mathrm{Ab}-\mathrm{V} 5$; (18) 32114 + Ab-V5; (19) $1301+\mathrm{Ab}-\mathrm{V} 5$; (20) $1381+\mathrm{Ab}-\mathrm{V} 5$; (21) Ab-V5 + T. pool; (22) $32110+T$. pool; (23) $32114+T$. pool; (24) $1301+T$. pool; (25) $1381+T$. pool; (26) 32110+ $32114+\mathrm{Ab}-\mathrm{V} 5$; (27) $32110+\mathrm{Ab}-\mathrm{V} 5+T$. pool; (28) $32110+32114+\mathrm{Ab}-\mathrm{V} 5+T$. pool; (29) $32110+32114+\mathrm{Ab}-\mathrm{V} 5+T$. pool $+1301+1381$; (30) control (no microorganisms). 
A significant increase was observed in the transpiration rate $(\mathrm{E})$ of soybean plants treated with BRM 32113 compared to that of control plants (Figure 1B). Transpiration is important for the thermal maintenance of the plant, controlling plant turgidity and osmotic pressure and allowing water to serve as a means of conducting mineral nutrients to all plant tissues (DEXTRO, 2019). Therefore, the use of beneficial microorganisms such as those used in our study could be important in improving plant gas exchange parameters, including the transpiration rate, and could be very advantageous for plant development. On the other hand, there were no significant differences in stomatal conductance (Ci) and leaf temperature (Tleaf) between microbially treated and control plants (Figure 2A and B). Therefore, the microorganisms used in this trial had little effect on the majority of gas exchange parameters. However, these microorganisms can affect other variables that affect plant development and lead to effects on grain yield.
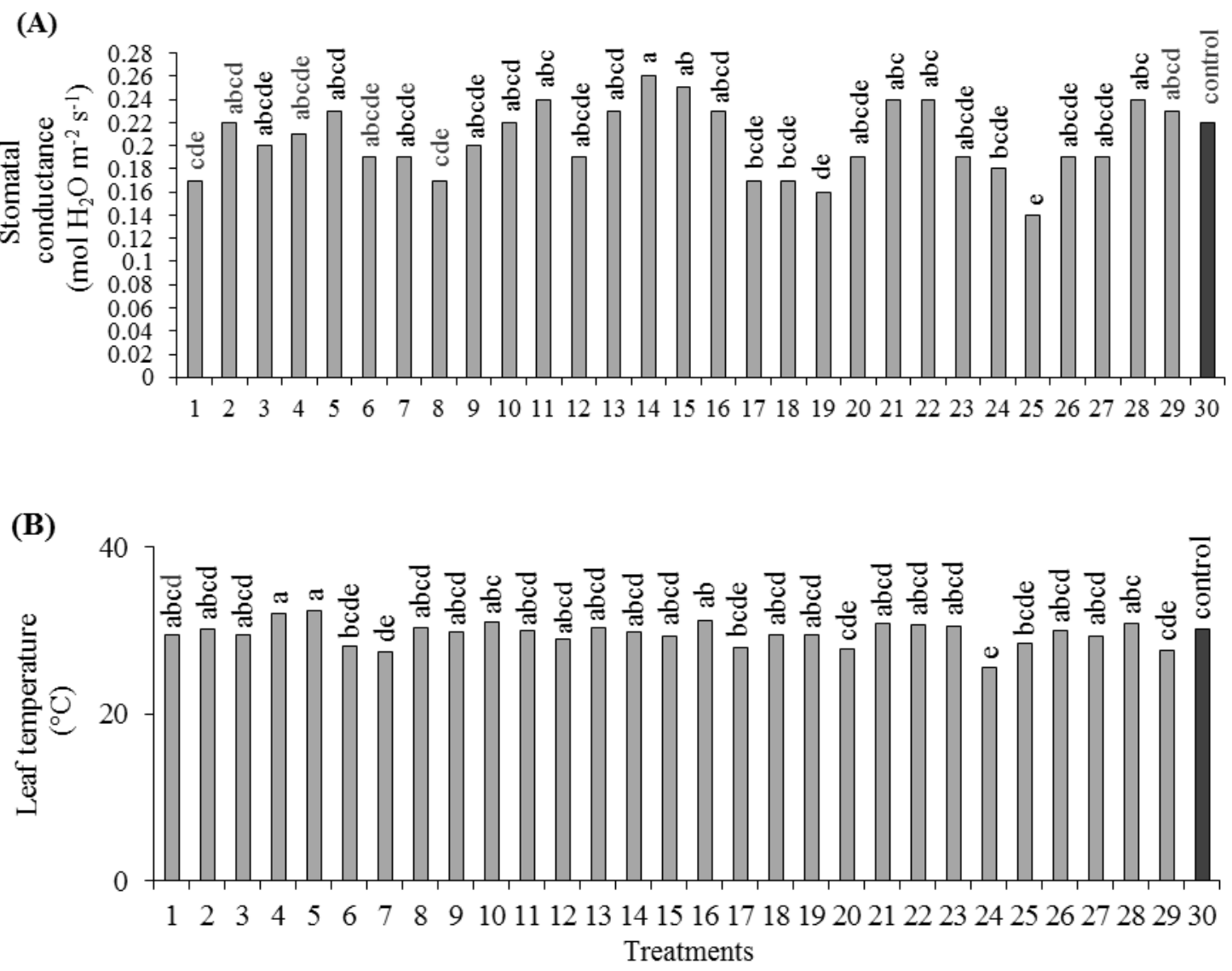

Figure 2. (A) Stomatal conductance, gs $\left(\mathrm{mol} \mathrm{H}_{2} \mathrm{O} \mathrm{m} \mathrm{m}^{-2} \mathrm{~s}^{-1}\right)$ and (B) leaf temperature, Tleaf $\left({ }^{\circ} \mathrm{C}\right)$ of soybean plants treated with beneficial microorganisms alone or in a mixture. *Means followed by the same letter in columns do not differ from each other by the LSD test. Comparisons between the treatments and the control that were significant by the Dunnett test at a significance level of 0.05 are indicated by **. Treatments: (1) BRM 32109; (2) BRM 32110; (3) BRM 32111; (4) BRM 32112; (5) BRM 32113; (6) BRM 32114; (7) 1301; (8) 1381; (9) T. asperellum pool (T. pool); (10) Ab-V5; (11) $32110+$ 32114 ; (12) $1301+32110$; (13) $1381+32110$; (14) $1301+32114$; (15) $1381+32114$; (16) $1301+1381$; (17) $32110+\mathrm{Ab}-$ V5; (18) $32114+$ Ab-V5; (19) $1301+$ Ab-V5; (20) $1381+$ Ab-V5; (21) Ab-V5 + T. pool; (22) $32110+T$. pool; (23) 32114 $+T$. pool; (24) 1301+ T. pool; (25) $1381+T$. pool; (26) 32110+32114 + Ab-V5; (27) $32110+$ Ab-V5 + T. pool; (28) $32110+32114+$ Ab-V5 + T. pool; (29) $32110+32114+$ Ab-V5 + T. pool $+1301+1381$; (30) control (no microorganisms).

Only soybean plants treated with Ab-V5 showed a significant increase in shoot biomass compared with the control plants (Figure 3A). Maurício Filho, Silva and Souza (2018) also found higher dry mass in soybean shoots coinoculated with Azospirillum sp. and Bradyrhizobium sp. than in soybean shoots treated with standard inoculation (Bradyrhizobium sp. only). This may explain the good results obtained from Ab-V5 applied in combination with Bradyrhizobium japonicum (as in this study); the combination may have enhanced the effects of both isolates. 

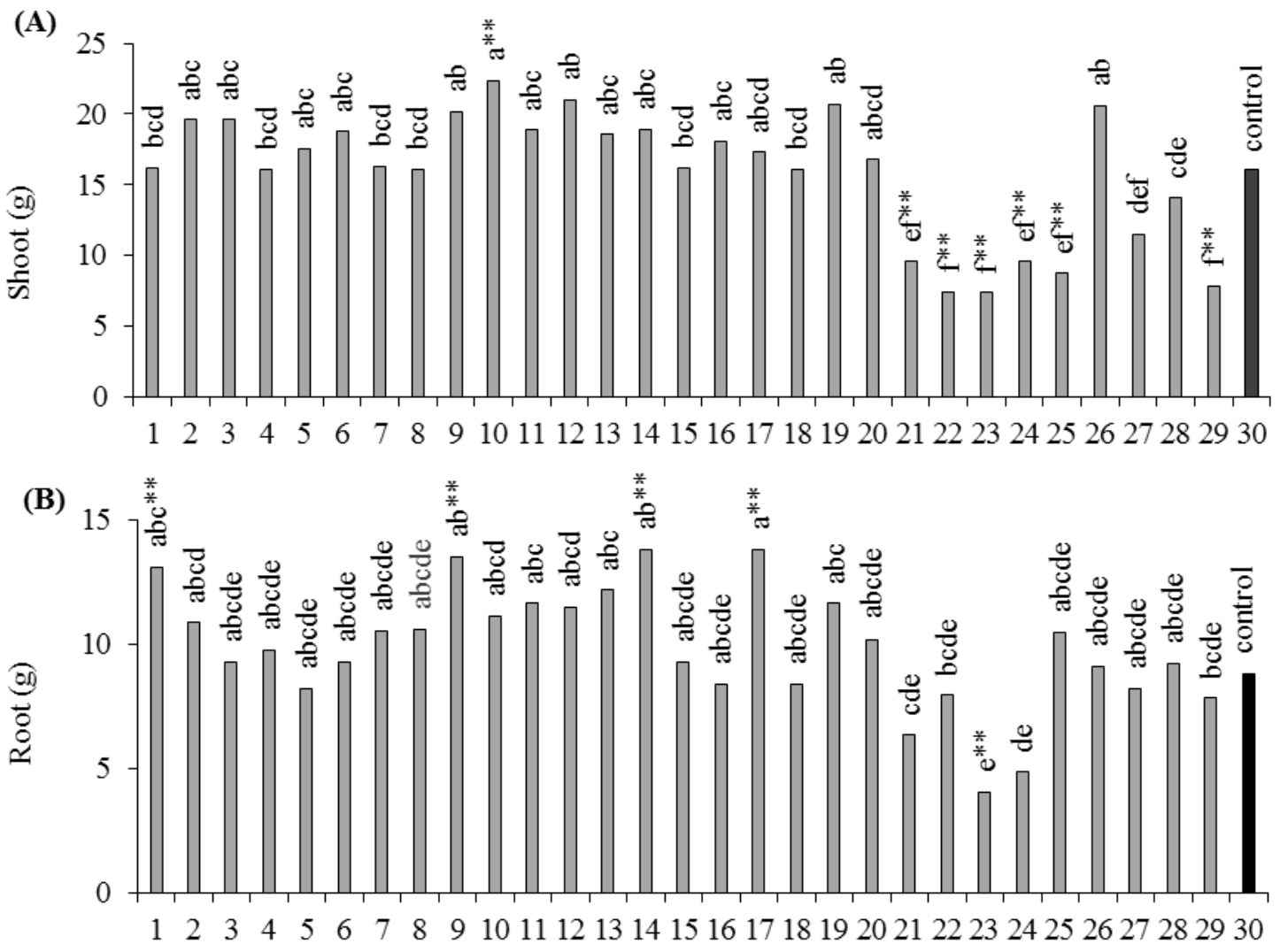

(C)

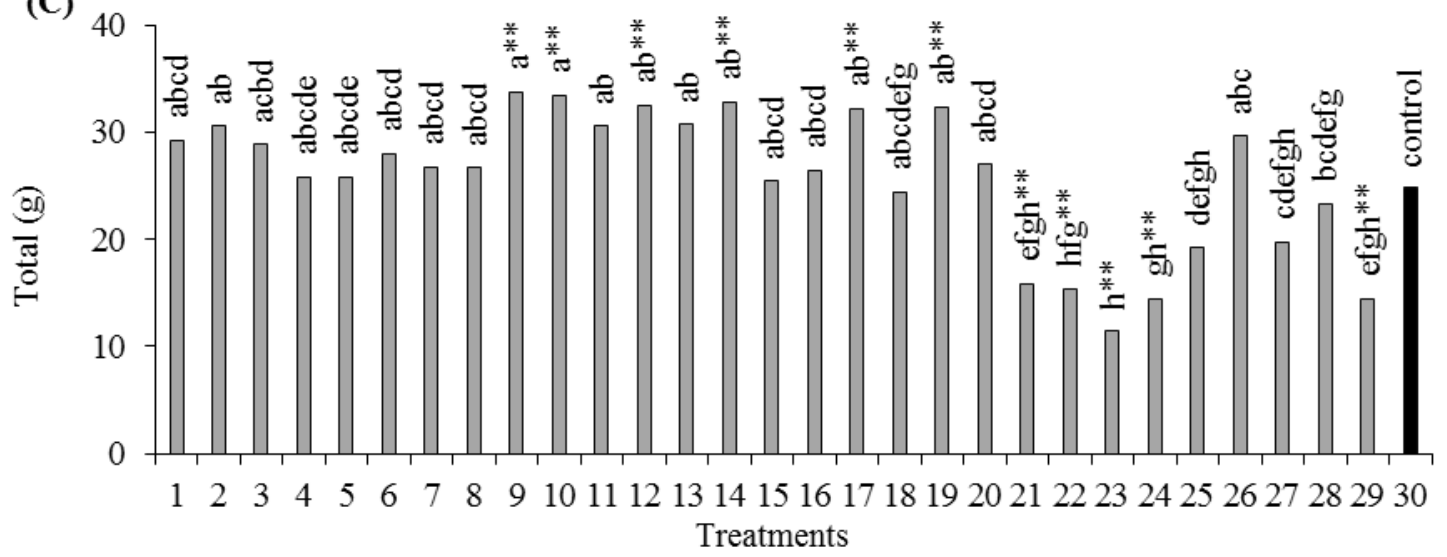

Figure 3. (A) Shoot biomass, (B) root biomass and (C) total biomass of soybean plants treated with beneficial microorganisms alone or in a mixture. *Means followed by the same letter in columns do not differ from each other by the LSD test. Comparisons between the treatments and the control that were significant by the Dunnett test at a significance level of 0.05 are indicated by **. Treatments: (1) BRM 32109; (2) BRM 32110; (3) BRM 32111; (4) BRM 32112; (5) BRM 32113; (6) BRM 32114; (7) 1301; (8) 1381; (9) T. asperellum pool (T. pool); (10) Ab-V5; (11) 32110 + 32114; (12) 1301 + 32110; (13) 1381 + 32110; (14) $1301+32114$; (15) $1381+32114$; (16) $1301+1381$; (17) $32110+$ Ab-V5; (18) $32114+$ Ab-V5; (19) $1301+$ Ab-V5; (20) $1381+$ Ab-V5; (21) Ab-V5 + T. pool; (22) $32110+T$. pool; (23) $32114+T$. pool; (24) 1301+T. pool; (25) $1381+T$. pool; (26) $32110+32114+\mathrm{Ab}-\mathrm{V} 5$; (27) $32110+\mathrm{Ab}-\mathrm{V} 5+T$. pool; (28) $32110+32114+\mathrm{Ab}$ -V5 + T. pool; (29) $32110+32114+\mathrm{Ab}-\mathrm{V} 5+T$. pool $+1301+1381$ and (30) control (no microorganisms).

The plants treated with BRM 32109, the $T$. asperellum pool, BRM $32110+$ Ab-V5, and $1301+$ BRM 32114 showed significantly higher root biomass than the control plants (Figure 3B). Several studies on the beneficial effects of PGPR on plants have reported that the biomass increase may be due to increased photosynthetic capacity. Nascente et al. (2017) found similar increases in the biomass accumulation of upland rice treated with the BRM
32109 isolate, and the biomass increases were correlated with an increase in the photosynthetic rate. However, in our study, the soybean plants had a high photosynthetic rate and did not show an increase in shoot biomass, only in root biomass. This suggests that a direct correlation such as that observed in rice may not exist. In this case, this difference may be due to the occurrence of natural factors or due to biotic or abiotic stresses. Similarly, 
Chagas et al. (2017), evaluating the effect of Trichoderma on soybean crops, found higher root biomass at 21 days after seedling emergence in treated plants than in control plants. These results corroborate ours, in which the $T$. asperellum pool was one of the most efficient microorganisms for increasing the root biomass of soybean plants. Braga Junior et al. (2018) showed that the inoculation of soybeans with Bacillus subtilis increased the dry biomass of the shoots and roots of the plants. Maurício Filho, Silva and Souza (2018) found a higher dry mass of soybean roots when the plants were coinoculated with Azospirillum sp. and Bradyrhizobium $s p$. These results, similar to those in this study, also confirm the effect of PGPR on the increase in the root biomass of soybean plants.

Soybean plants treated with the T. asperellum pool, Ab-V5, $1301+$ BRM 32110, $1301+$ BRM 32114, BRM $32110+$ Ab-V5 and $1301+$ Ab-V5 accumulated the highest total dry biomass, which was significantly higher than that in the control plants (Figure 3C). Chagas et al. (2017) also found higher shoot dry mass in soybean plants inoculated with Bacillus subtilis and Trichoderma asperellum and the combination of both compared to that in the control (without inoculation) at two evaluation times, 20 and 40 days after emergence (DAE). For the root and total dry mass evaluated at 20 DAE, the treatment with only Trichoderma inoculation was superior to the control; at $40 \mathrm{DAE}$, all inoculation treatments were superior to the control.

The soybean plants that presented a lower accumulation of shoot, root and total biomass than the control plants were those that combined the $T$. asperellum pool with rhizobacteria, i.e., $1301+T$. asperellum pool; Ab-V5 + T. asperellum pool; 1381 + T. asperellum pool; BRM $32110+$ BRM $32114+$ $\mathrm{Ab}-\mathrm{V} 5+T$. asperellum pool $+1301+1381$; BRM $32110+T$. asperellum pool and BRM $32114+T$. asperellum pool for the shoot dry biomass; BRM $321114+T$. asperellum pool for the root dry biomass and $\mathrm{Ab}-\mathrm{V} 5+T$. asperellum pool; $32114+$ $32110+\mathrm{Ab}-\mathrm{V} 5+$ T. asperellum pool $+1301+1381$; BRM $32110+T$. asperellum pool; $1301+T$. asperellum pool and BRM $32114+T$. asperellum pool for the total dry biomass. This finding may indicate negative interactions between the $T$. asperellum pool and the rhizobacteria used in our trials. On the other hand, the soybean plants accumulated high levels of root and total dry biomass when the seeds were treated with only the $T$. asperellum pool (Figure 3B and C). Both Trichoderma and PGPR provide several benefits to plant development, but little is known about the effects of combining Trichoderma with the bacterial isolates in this study.
For the nutrient analysis, soybean plants treated with the $T$. asperellum pool +32114 exhibited higher nitrogen $(\mathrm{N})$ and $(\mathrm{K})$ contents in shoots than the control plants (Figure 4A and C).

For phosphorus $(\mathrm{P})$, soybean plants treated with the $\mathrm{Ab}-\mathrm{V} 5+T$. asperellum pool and BRM $32110+T$. asperellum pool had higher shoot $\mathrm{P}$ content than the control (Figure 4B). Growthpromoting microorganisms have been shown to increase nutrient uptake as they interact with different crops (WARWATE et al., 2017). This is because the larger root system provided by the beneficial microorganisms increases the contact area of the roots with the soil and improves water and nutrient absorption (ASARI et al., 2016). Regarding $\mathrm{P}$, our results corroborate those of Braga Júnior et al. (2017), where several tested rhizobacteria isolates provided higher phosphorus content in soybean soil and sprouts than in noninoculated plants both under natural phosphate fertilization and without fertilizer use. Different isolates of Trichoderma spp. tested in vitro by Ribas et al. (2016) had the ability to solubilize phosphate, indicating the possible application of this fungus as a biofertilizer. Therefore, the combination of rhizobacteria and the Trichoderma pool (treatments 21 and 22, Figure 4B) in our study may have favored $\mathrm{P}$ solubilization and accumulation in the shoots of the soybean plants.

Beneficial microorganisms can increase the accumulation of nutrients, such as $\mathrm{K}$, in plants by promoting root development, which allows greater nutrient access and absorption, and by improving absorption mechanisms (AHEMAD; KIBRET, 2014). In this experiment, the $32114+T$. asperellum pool mixture led to higher shoot $\mathrm{K}$ accumulation but did not increase root biomass (Figure 4C). This suggests that the high $\mathrm{K}$ accumulation in soybean plants may have been due to the improvement of the $\mathrm{K}$ absorption mechanism by microorganisms and not due to greater root development.

The BRM 32113 treatment was the only treatment that provided significant increases in the $\mathrm{N}$ and $\mathrm{K}$ contents of the roots of soybean plants compared to the control (Figure 5A and $\mathrm{C}$ ). This treatment also led to a higher transpiration rate in the soybean plants. These results may be related, since plant transpiration is fundamental for the absorption of water and mineral nutrients from the soil.

In terms of $\mathrm{P}$ content, soybean plants treated with $1301+32110$ and $32110+\mathrm{Ab}-\mathrm{V} 5+$ the $T$. asperellum pool accumulated significantly more $\mathrm{P}$ than the control plants (Figure 5B). These microorganisms act as biostimulants for root growth by producing phytohormones. Most of these microorganisms are also able to solubilize phosphorus, and some are able to fix nitrogen (CARDOSO; ANDREOTE, 2016). 
(A)

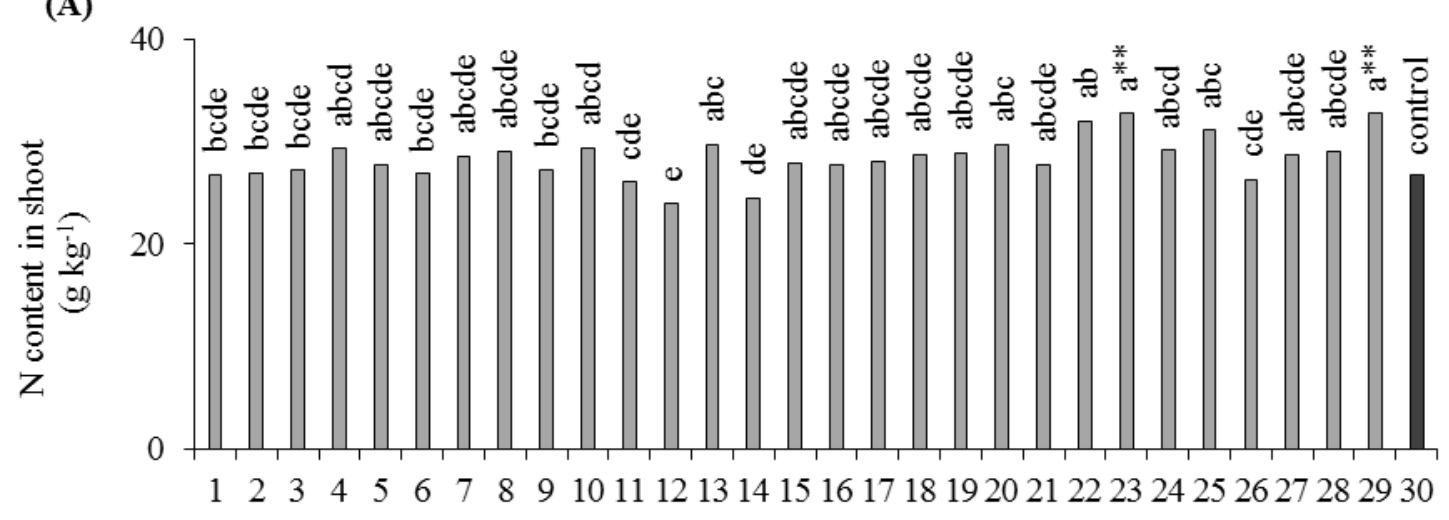

(B)

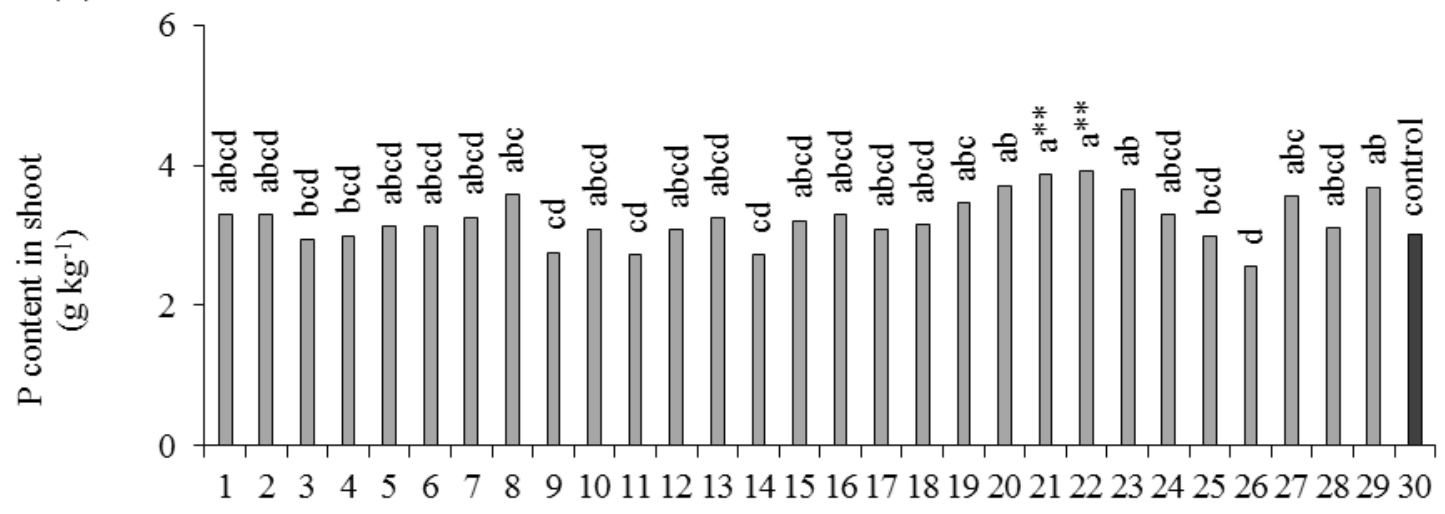

(C)

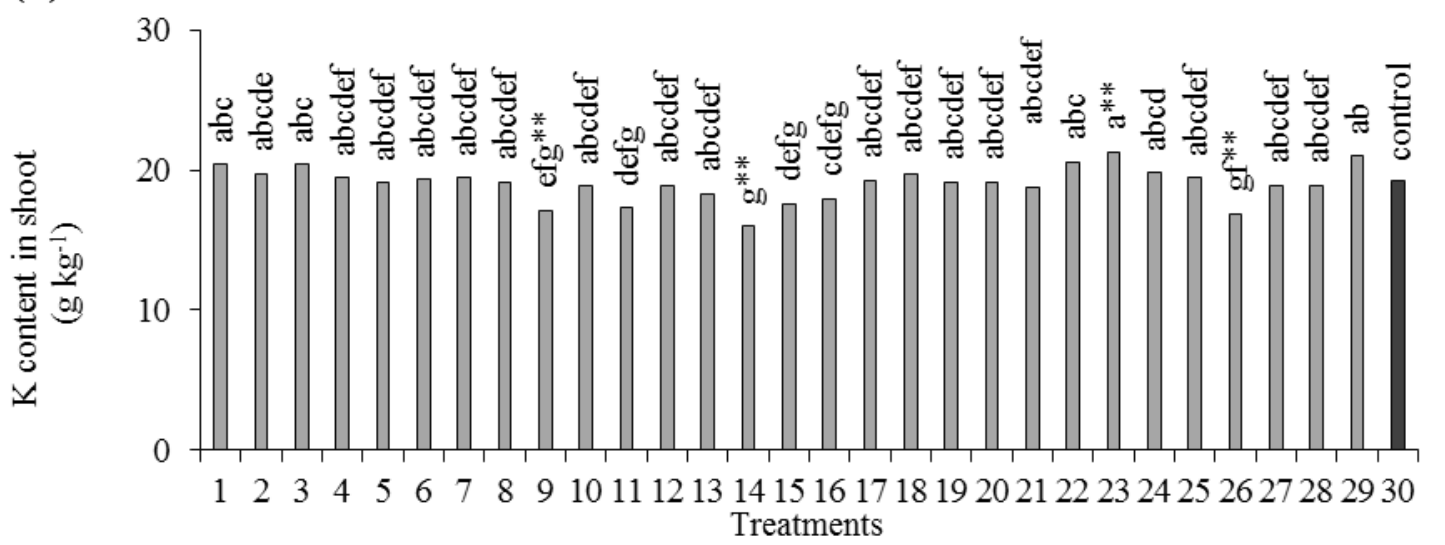

Figure 4. (A) Nitrogen $(\mathrm{N})$, (B) phosphorus $(\mathrm{P})$, and $(\mathrm{C})$ potassium $(\mathrm{K})$ contents of shoots of soybean plants treated with beneficial microorganisms alone or in a mixture. *Means followed by the same letter in columns do not differ from each other by the LSD test. Comparisons between the treatments and the control that were significant by the Dunnett test at a significance level of 0.05 are indicated by **. Treatments: (1) BRM 32109; (2) BRM 32110; (3) BRM 32111; (4) BRM 32112; (5) BRM 32113; (6) BRM 32114; (7) 1301; (8) 1381; (9) T. asperellum pool (T. pool); (10) Ab-V5; (11) $32110+$ 32114; (12) $1301+32110$; (13) $1381+32110$; (14) $1301+32114$; (15) $1381+32114$; (16) $1301+1381$; (17) $32110+\mathrm{Ab}-$ V5; (18) $32114+$ Ab-V5; (19) $1301+$ Ab-V5; (20) 1381 + Ab-V5; (21) Ab-V5 + T. pool; (22) 32110 + T. pool; (23) 32114 $+T$. pool; (24) 1301+ T. pool; (25) $1381+T$. pool; (26) 32110+32114 + Ab-V5; (27) $32110+$ Ab-V5 + T. pool; (28) $32110+32114+$ Ab-V5 + T. pool; (29) $32110+32114+$ Ab-V5 + T. pool + $1301+1381$; (30) control (no microorganisms). 

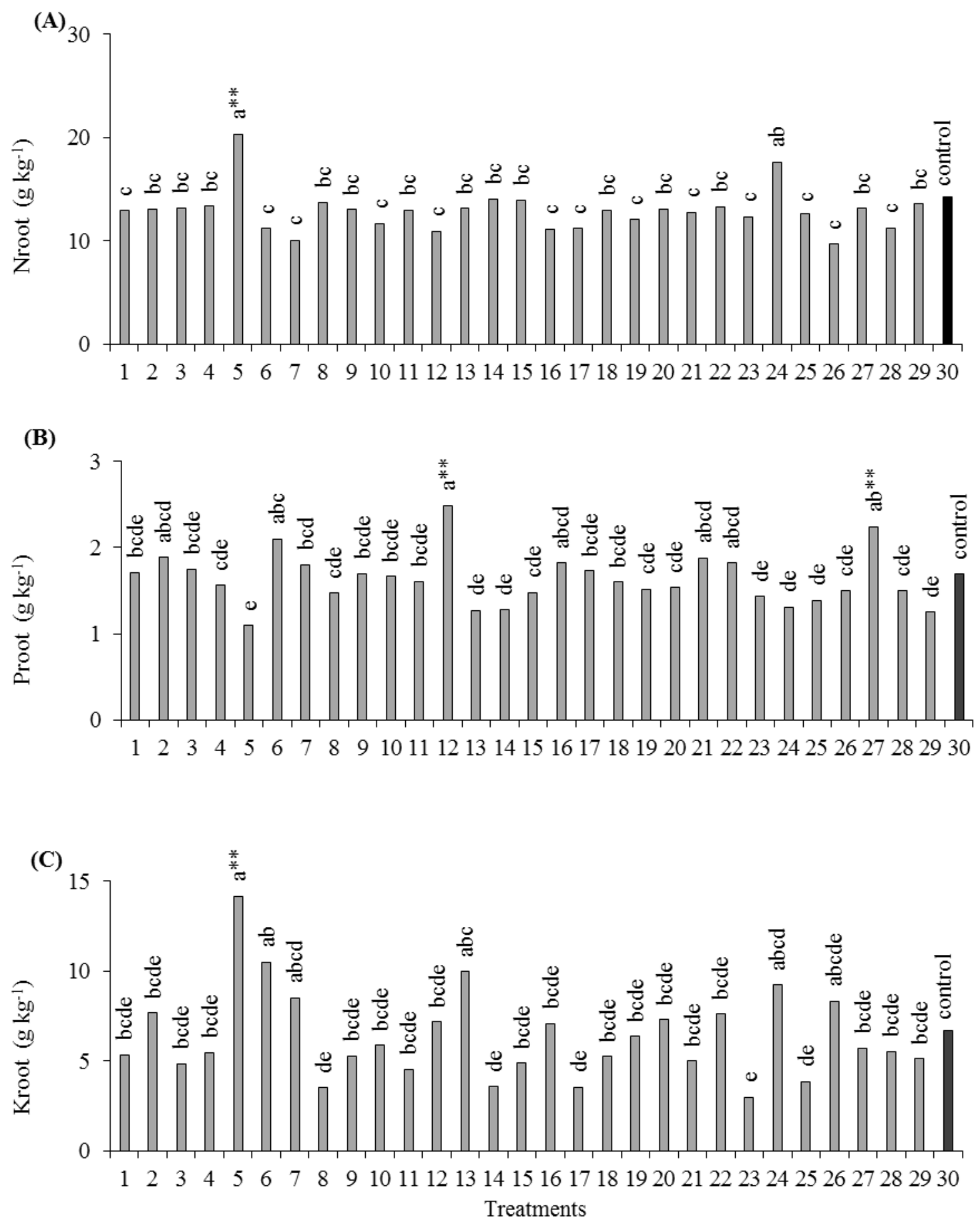

Figure 5. (A) Nitrogen $(\mathrm{N})$, (B) phosphorus $(\mathrm{P}),(\mathrm{C})$ potassium $(\mathrm{K})$ nutrient contents of root of soybean plants treated with beneficial microorganisms, use alone or in a mixture. *Means followed by the same letter in columns do not differ from each other by the LSD test. Comparisons between treatments and control, significant by the Dunnett test, at significance level 0.05, are indicated by **. Treatments: (1) BRM 32109; (2) BRM 32110; (3) BRM 32111; (4) BRM 32112; (5) BRM 32113; (6) BRM 32114; (7) 1301; (8) 1381; (9) T. asperellum pool (T. pool); (10) Ab-V5; (11) $32110+32114$; (12) $1301+$ 32110; (13) 1381 + 32110; (14) 1301 + 32114; (15) $1381+32114$; (16) 1301 + 1381; (17) 32110 + Ab-V5; (18) $32114+$ Ab-V5; (19) $1301+$ Ab-V5; (20) $1381+$ Ab-V5; (21) Ab-V5 + T. pool; (22) $32110+$ T. pool; (23) $32114+T$. pool; (24) 1301+ T. pool; (25) $1381+$ T. pool; (26) 32110+32114 + Ab-V5; (27) $32110+$ Ab-V5 + T. pool; (28) $32110+32114+$ Ab-V5 + T. pool; (29) $32110+32114+\mathrm{Ab}-\mathrm{V} 5+T$. pool $+1301+1381$ and (30) control (no microorganism). 
The principal component analysis showed that the variability of treatments with microorganisms alone and in combination in terms of gas exchange (photosynthesis, transpiration rate, stomatal conductance and leaf temperature), biomass production (shoot, root and total), shoot nutrient accumulation (N-shoot, P-shoot and K-shoot) and root nutrient accumulation (N-root, P-root and $\mathrm{K}$ root) were best described by three main components (PCs) that accounted for $65.38 \%$ of the data variation, i.e., PC1 (32.70\%), PC2 (20.51\%) and PC3 (12.17\%) (Table 3, Figure 6).

Table 3. Contribution of each variable in the projection of the components. Correlation of variables related to soybean (Glycine max.) growth promotion from beneficial microorganisms alone and in combination with a significance level of $\mathrm{p}$ $<0.05$.

\begin{tabular}{lccc}
\hline Variable & PC1 & PC2 & PC3 \\
\hline Photosynthesis & 0.079 & 0.310 & 7.045 \\
Transpiration rate & 0.893 & 34.668 & 0.177 \\
Stomatal conductance & 0.666 & 25.741 & 2.492 \\
Leaf temperature & 1.640 & 20.133 & 0.001 \\
Shoot & 19.293 & 0.450 & 1.332 \\
Root & 12.896 & 4.811 & 2.002 \\
Total & 20.158 & 1.746 & 0.067 \\
N-shoot & 15.629 & 0.006 & 4.814 \\
P-shoot & 13.259 & 0.212 & 1.664 \\
K-shoot & 12.898 & 2.230 & 7.645 \\
N-root & 1.353 & 7.112 & 1.926 \\
P-root & 1.089 & 0.079 & 43.474 \\
K-root & 0.147 & 2.483 & 27.361 \\
Data variation explained & $32.70 \%$ & $20.51 \%$ & $12.17 \%$ \\
\hline
\end{tabular}

The factor map (biplot) shows groups of variables (arrows) denoting positive and negative correlations with each principal component (PC); the length of the arrow indicates the magnitude of each response to each PC (Figure 6). For example, PC1 was positively correlated with photosynthesis; shoot, root and total biomass; and phosphorus and potassium accumulation in the root but was negatively correlated with $\mathrm{N}, \mathrm{P}$ and $\mathrm{K}$ accumulation in the shoot and nitrogen accumulation in the root. On the other hand, PC2 was positively correlated with the transpiration rate, stomatal conductance; leaf temperature; $\mathrm{N}$ and $\mathrm{P}$ accumulation in the shoot; and $\mathrm{N}, \mathrm{P}$ and $\mathrm{K}$ accumulation in the root and negatively correlated with photosynthesis; shoot, root and total biomass production; and accumulation of $\mathrm{K}$ in the shoot. PC3 was positively correlated with photosynthesis; shoot and total biomass production; accumulation of $\mathrm{P}$ and $\mathrm{K}$ in the shoot; and accumulation of $\mathrm{N}, \mathrm{P}$ and $\mathrm{K}$ in the roots and was negatively correlated with the transpiration rate, leaf temperature, stomatal conductance, root biomass and $\mathrm{N}$ accumulation in the shoot. The total and shoot biomass variables showed the largest contributions to PC1 (85\% and $82 \%$, respectively). On the other hand, the transpiration rate made the largest contribution to $\mathrm{PC} 2$ variability $(92 \%)$ and root $\mathrm{P}$ accumulation made the largest contribution to $\mathrm{PC} 3$ variability $(68 \%)$.

Based on the visualized quality of the treatments with microorganisms alone and in combination for the analyzed variables, treatments $24(1301+$ pool $)$ and $26(32110+32114+$ Ab-V5) had the highest positive correlations with shoot, root and total biomass (Figure 6). Transpiration rate, stomatal conductance and leaf temperature were positively correlated with isolate 1 (BRM 32109). Nitrogen accumulation in shoots was positively correlated with treatments $13(1381+32110), 27$ $(32110+\mathrm{Ab}-\mathrm{V} 5+T$. asperellum pool) and 29 $(32110+32114+$ Ab-V5 + T. asperellum pool + $1301+1381)$. The accumulation of $\mathrm{P}$ and $\mathrm{K}$ in the shoot had strong correlations with treatments 16 $(1301+1381)$ and $28(32110+32114+\mathrm{Ab}-\mathrm{V} 5+T$. asperellum pool). Root nitrogen accumulation ( $\mathrm{N}$ root) was positively correlated with treatments 16 $(1301+1381)$ and $18(32114+\mathrm{Ab}-\mathrm{V} 5)$. In the same way, phosphorus and potassium accumulation in the roots (P-root and K-root) were positively correlated with isolate 1 (BRM 32109) and combination 26 $(32110+32114+$ Ab-V5). 
(A) PCA1 X PCA2

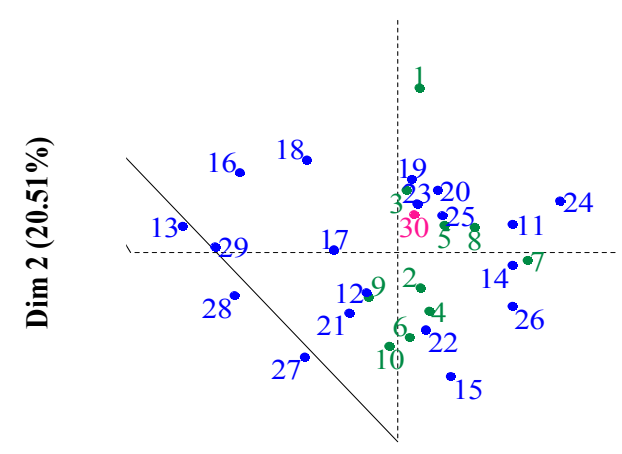

Dim $1(32.70 \%)$

(B) PCA1 X PCA3

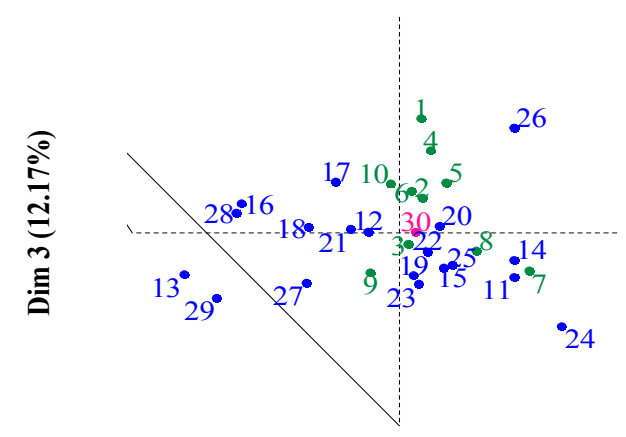

Dim $1(32.70 \%)$

(C) PCA2 X PCA3

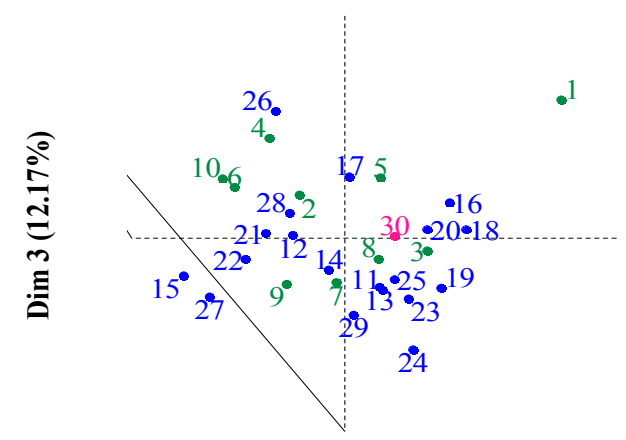

Dim 2 (20.51\%)

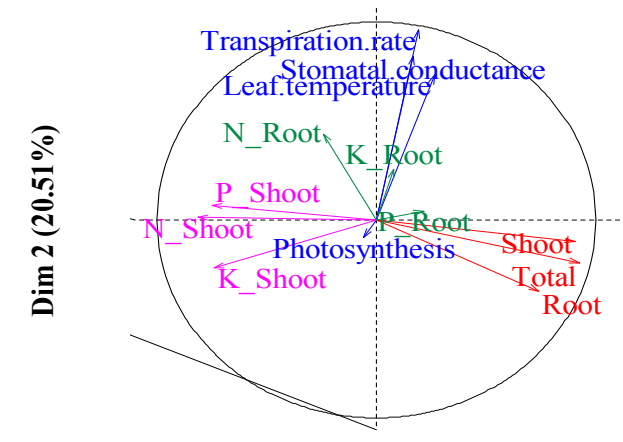

$\operatorname{Dim} 1(32.70 \%)$

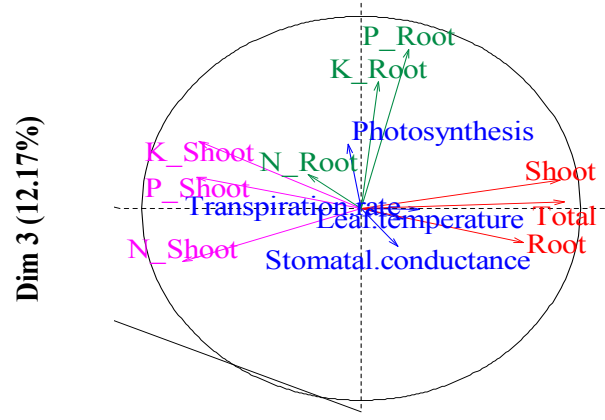

Dim 1 (32.70\%)

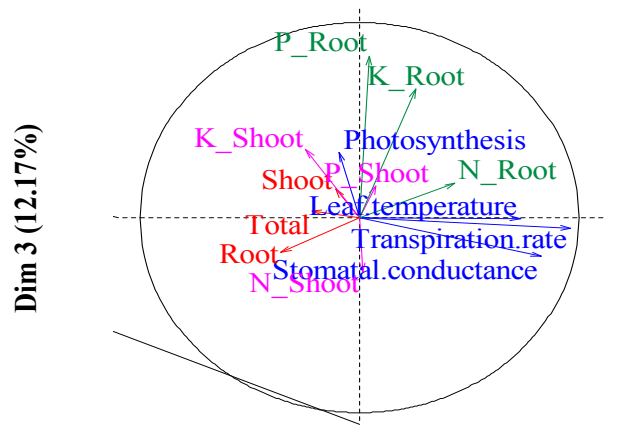

$\operatorname{Dim} 2(20.51 \%)$

Figure 6. Principal component analysis (PCA) explaining correlations among variables and among 30 treatments with individual and combined microorganisms. Three main components (PCs) accounted for $65.38 \%$ of the data variation. Treatments: isolates; (1) BRM 32109; (2) BRM 32110; (3) BRM 32111; (4) BRM 32112; (5) BRM 32113; (6) BRM 32114; (7) 1301; (8) 1381; (9) T. asperellum pool (T. pool); (10) Ab-V5; in combination; (11) $32110+32114$; (12) $1301+$ 32110; (13) 1381 + 32110; (14) $1301+32114$; (15) 1381 + 32114; (16) $1301+1381$; (17) 32110 + Ab-V5; (18) $32114+$ Ab-V5; (19) $1301+$ Ab-V5; (20) $1381+$ Ab-V5; (21) Ab-V5 + T. pool; (22) $32110+T$. pool; (23) $32114+T$. pool; (24) 1301+ T. pool; (25) $1381+T$. pool; (26) 32110+32114 + Ab-V5; (27) $32110+\mathrm{Ab}-\mathrm{V} 5+T$. pool; (28) $32110+32114+\mathrm{Ab}$ -V5 + T. pool; (29) $32110+32114+$ Ab-V5 $+T$. pool $+1301+1381$; control (30) no microorganisms.

The potential use of beneficial microorganisms for crop development, physiological activities and nutrient accumulation has strong worldwide appeal, especially since it is a lowinvestment-cost technology that is easy to apply and use, does not create pollution, and places the sustainable intensification of modern agriculture in a desirable context. In this study, the single and combined microorganisms that deserve attention are the T. asperellum pool, Ab-V5, BRM $32110+\mathrm{Ab}-$ V5, $1301+$ Ab-V5, $1301+$ BRM 32110, and $1301+$ BRM 32114, since they provided on average $25 \%$ 
increases in total biomass production compared the control plants. These results are even more relevant because they are microorganisms that were selected from upland rice fields rather than soybean fields. These results corroborate Ahemad and Kibret (2014), who reported that the same microorganisms can promote plant development in different species. The results are relevant from a commercial point of view since agriculture businesses are looking for microorganisms that improve plant development in many crops. Research performed under field conditions is necessary to confirm the promising results found under greenhouse conditions.

\section{CONCLUSIONS}

Microorganisms led to improvements in gas exchange parameters and dry shoot and root biomass as well as macronutrient content in the shoots and roots of soybean plants. In addition, the microorganisms T. asperellum pool, Ab-V5, $1301+$ $32110,1301+32114,1301+$ Ab-V5 and $32110+$ $\mathrm{Ab}-\mathrm{V} 5$ led to the greatest accumulation of total biomass in soybean plants of all treatments, with values on average $25 \%$ higher than those in the control treatment. Therefore, our results suggest that the use of beneficial microorganisms in cropping systems is very promising.

\section{ACKNOWLEDGMENTS}

The authors are grateful to Embrapa for the infrastructure for conducting this research, to $\mathrm{CNPq}$ and FAPEG for financial assistance with this research and to the $\mathrm{CNPq}$ for the master's degree awarded to the first author and for the scholarship in research productivity awarded to the second and third authors. The authors also thank the researchers from Embrapa Rice and Beans, Enderson Petronio de Brito Ferreira and Mabio Chrisley Lacerda, and the students Maria Eugênia Silva Guedes, Adriana Mendonça Barbosa and Marina Teixeira Arriel Elias for their collaboration with the experiment.

\section{REFERENCES}

AHEMAD, M. S.; KIBRET, M. Mechanisms and applications of plant growth promoting rhizobacteria: current perspective. Journal of King Saud University, 26: 1-20, 2014.

\footnotetext{
APROSOJA. Produzindo com sustentabilidade. 2018. Disponível em: < https:// aprosojabrasil.com.br/comunicacao/blog/2018/12/11/ produzindo-com-sustentabilidade/ $>$ Acesso em: 10 jan 2019.
}

ASARI, S. et al. Analysis of plant growth-promoting 606 properties of Bacillus amyloliquefaciens UCMB5113 using Arabidopsis thaliana as 607 host plant. Planta, 245: 15-30, 2016.

BÁRBARO-TORNELI, L. M. et al. Influência de modos de aplicação da coinoculação no desempenho agronômico de soja. Nucleus. Edição Especial, 2018.

BRAGA JÚNIOR, G. M. et al. Soybean growth promotion and phosphate solubilization by bacillus subtilis strains in greenhouse. International Journal of Current Research, 9: 50914-50918, 2017.

BRAGA JÚNIOR, G. M. et al. Efficiency of inoculation by Bacillus Subtilis on soybean biomass and productivity. Revista Brasileira de Ciências Agrárias, 13: 1-6, 2018.

CANELLAS, L. P. et al. Foliar application of plant growth-promoting bacteria and humic acid increase maize yields. Journal of Food Agriculture Environment, 13: 131-138, 2015.

CARDOSO, E. J. B. N.; ANDREOTE, F. D. Microbiologia do solo. 2. ed. Piracicaba, SP: ESALQ,2016. 221 p.

CHAGAS, L. F. B. et al. Efficiency of Trichoderma spp. as a growth promoter of cowpea (Vigna unguiculata) and analysis of phosphate solubilization and indole acetic acid synthesis. Brazilian Journal of Botany, 38: 1-11, 2016.

CHAGAS, L. F. B. et al. Bacillus subtilis e Trichoderma $s p$. no incremento da biomassa em plantas de soja, feijão-caupi, milho e arroz. Revista Agri-Environmental Sciences, 3: 10-18, 2017.

DEXTRO, R. B. Transpiração vegetal. Infoescola. Disponível em: <https://www.infoescola.com/ biologia/transpiracao-vegetal/ > Acesso em: $18 \mathrm{dez}$. 2019.

DONAGEMA, G. K. et al. Manual de métodos de análise de solos. 2. ed. rev. Rio de Janeiro, RJ: Embrapa Solos, 2011. 230 p. (Documentos/Embrapa Solos, 132).

FILIPPI, M. C. C. et al. Leaf blast (Magnaporthe oryzae) suppression and growth promotion by rhizobacteria on aerobic rice in Brazil. Biological Control, 58: 160-166, 2011.

FRANÇA, S. K. S. et al. Biocontrol of sheath blight by Trichoderma asperellum in tropical lowland rice. Agronomy for Sustainable Development, 35: 317 $324,2015$. 
KADO, C. J.; HESKETT, M. G. Selective media for isolation of Agrobacterium, Corynebacterium, Erwinia, Pseudomonas and Xanthomonas. Phytopathology, 60: 969-976. 1970.

KASSAMBARA, A. Factoextra: Extract and Visualize the Results of Multivariate Data Analyses. R Package Version 1.0.3. 2015.

SPOLAOR, L. T. et al. Bactérias promotoras de crescimento associadas a adubação nitrogenada de cobertura no desempenho agronômico de milho pipoca. Bragantia, 75: 33-40, 2016.

MALAVOLTA, E. ; VITTI, G. C. ; OLIVEIRA, S. A. Avaliação do estado nutricional das plantas: princípios e aplicações. 2 ed. Piracicaba, SP: POTAFOS, 1997. 319 p.

MAURÍCIO FILHO, J. M.; SILVA, C. H. S.; SOUZA, J. E. B. Desempenho agronômico e produtividade da cultura da soja com a coinoculação de Bradyrhizobium e Azospirillum brasilense. Ipê Agronomic Journal, 2: 48-59, 2018.

NASCENTE, A. S. et al. Biomass, gas exchange, and nutrient contents in upland rice plants affected by application forms of microorganism growth promoters. Environmental Science and Pollution Research, 24: 2956-2965, 2017.

NUNES, J. L. S. Características da Soja (Glycine max). Agrolink. 2017. Disponível em: < https:// www.agrolink.com.br/culturas/soja/informacoes/ caracteristicas_361509.html $>$ Acesso em: $05 \mathrm{fev}$ 2019.

RIBAS, P. P. et al. Potencial in vitro para solubilização de fosfato por Trichoderma spp. Revista Brasileira de Biociências, 14: 70-75, 2016.

SANTOS, H. G. et al. Sistema brasileiro de classificação de solos. 5. ed. Brasília, DF: Embrapa, 2018. 356 p.

SAS INSTITUTE. The SAS system for windows. Estados Unidos, 1999. 1 CD-ROM.

SILVA, J. C. et al. Biocontrol of sheath blight on rice and growth promotion by Trichoderma isolates from the Amazon. Revista Ciências Agrárias, 55: 243-250, 2012.

UNITED STATES DEPARTMENT OF AGRICULTURE NATIONAL AGRICULTURAL STATISTICS SERVICE - USDA. (2019) Crop production. Disponível em: $<$ https:// www.nass.usda.gov/Publications/index.php $>$.

Acesso: 06 jan. 2020.
WARWATE, S. I. et al. The effect of seed priming with plant growth promoting rhizobacteria (PGPR) on growth of Coriander (Coriandrum sativum L.) seedling. International Journal of Current Microbiology and Applied Sciences, 6: 1926-1934, 2017.

This work is licensed under a Creative Commons Attribution-CC-BY https://creativecommons.org/licenses/by/4.0/ 